\title{
Mary, High Priest and Bishop
}

The descriptions of the women apostles in the last chapter help illuminate a second-century conflict over gender roles that is evinced in the New Testament letter 1 Timothy. Mainstream scholars agree that 1 Timothy was falsely attributed to Paul-that is, the real Paul did not write it. It was written by someone whom I call faux-Paul. Whoever the author of 1 Timothy was, he first specified that men should pray with their arms raised: "Men should pray, lifting up holy hands" (2:8 RSV). He then specified that a woman should "learn in silence with all submissiveness. I permit no women to teach or have authority over men. She is to stay silent" (2:11-12 RSV).

Almost certainly when writing these new rules, faux-Paul had in mind women leaders in some communities of Jesus followers, women like the women apostles of the last chapter. According to the authors who wrote the long narratives about Thecla, Irene, Mariamne, Nino, and Mary, these women lifted their holy hands to pray. They were not silent. They spoke, including when they prayed in front of crowds, when they cast out demons, and when they baptized people. They taught men as well as women. They were not submissive. Sometimes they had authority over men.

The author of 1 Timothy also may have wanted to contradict the reputation of the historical Timothy as a disciple of Paul who appointed women leaders who did all the things that 1 Timothy said they could not do. According to 1 Timothy, Paul himself wrote to Timothy and gave him those gendered rules. According to the narrative about Irene,

(C) The Author(s) 2019

A. Kateusz, Mary and Early Christian Women, https://doi.org/10.1007/978-3-030-11111-3_4 
however, Paul sent Timothy to teach and baptize Irene! Irene, of course, did not follow the gendered rules in 1 Timothy. She did not accept male authority over her. She was not silent. She preached and taught people, including men. For example, one passage describes her leading a crowd in prayer: "She turned to the whole crowd and said, 'My fellow believers, offer a prayer to God with me.' And she stretched out her hands and looked towards heaven, and prayed [out loud]."l Three more passages specify that Irene raised her hands to pray, including one that says she raised her arms to pray in front of the king and his army, ultimately teaching them. ${ }^{2}$ The author of the narrative about Irene and the scribe today known as faux-Paul not only had opposing views on gender roles for women-they also had opposing views on whether the historical Timothy and Paul had sanctioned women leaders.

\section{Jesus's Mother Versus 1 Timothy}

The authors of the Six Book narrative and I Timothy also had opposing views on gender roles for women. According to the Six Books author, Mary acted in direct conflict with the type of gendered rules specified in 1 Timothy. Perhaps most telling is a scene that takes place when Mary is about to die. The twelve male apostles-the original eleven plus the apostle Paul-return from their missions around the Mediterranean to see her one last time in Jerusalem. When they arrive, they gather around her. Mary lifts her holy hands and leads the prayer:

And when my Lady Mary heard these things from the Apostles she stretched out her hands to heaven and prayed, saying, "I worship and praise and sing and laud that I am not a mockery to the nations of the Gentiles ... and I will praise His gracious name for ever and ever. And I cannot glorify His grace sufficiently; that He hath sent His holy disciples to me." And after Mary had prayed, the Apostles set forth the censer of incense, and knelt with their faces down and prayed. ${ }^{3}$

The entire passage is in opposition to the rules in I Timothy-Mary raises her arms to pray, speaks the prayer, and has authority over men. The final line states that after Mary raised her arms and praised God, the men prostrated themselves. This describes Mary much as Sirach 
50:19-21 describes the Temple high priest: raising hands, praising God, and then the people prostrating themselves.

According to Leviticus 9:22, Deuteronomy 10:8 and 23:20, 1 Chronicles, and Sirach 50:20-21, high priests raised their hands and blessed people. In Luke 24:50, Jesus lifts his hands and blesses a crowd. The Six Books narrative also preserves scenes where Mary lifts her hands and blesses people. For example, the fifth-century Six Books palimpsest, the medieval Arabic, the medieval Ethiopic, and the Georgian Life of the Virgin all contain at least part of a scene where Mary lifts her hands and blesses a crowd of both men and women. ${ }^{4}$ The Ethiopic text preserves the fullest detail:

Many men and women came to Mary, and they prostrated themselves before her, saying, "Have mercy on us and forgive us, and do not cast us away, O master." And the blessed one, having extended her arms, blessed them and said, 'May the Lord receive your prayer and your petition ...'

Most likely, readers of the Six Books were aware of the scriptural resonance between such descriptions of Mary and descriptions of the Temple high priest.

The palimpsest text depicted Mary with authority over the male apostles, "serving in essence as their liturgical leader,"7 essentially serving as the high priest of the men in the line of apostolic succession, that is, serving as the bishop of bishops. This depiction of Mary apparently became problematic for some scribes because it underwent various forms of scribal redaction. For example, the sixth-century scribe excised that the apostles prostrated themselves before Mary. ${ }^{8}$ The scribe behind the Ethiopic translation preserved that they "prostrated themselves on the earth"-but excised that Mary raised her hands to pray and further changed the text so that Mary was seen as prostrate like the men. ${ }^{9}$

Mary raising her hands to pray, which 1 Timothy associates with men, appears to have become a significant concern for later scribes. For example, the homilies attributed to Theoteknos of Livias, Modestus of Jerusalem, Andrew of Crete, Germanus of Constantinople, John of Damascus, and Theodore the Studite, all omit that she raised her hands. ${ }^{10}$ Mary as the liturgical leader of the male apostles appears to have been more of a concern to some Dormition scribes than even the 
presence of the Great Angel. The Palm text of an eleventh-century Greek manuscript, which preserves the Great Angel, nonetheless replaces Mary as the prayer leader with Peter. According to its text, after the apostles arrived to see Mary, Peter raised his arms and prayed. And, after Peter "exhorted the crowd until dawn, the sun rose, Mary got up and went outside, and she recited the prayer that the angel had given her." 11

The scribe of a Gaelic Dormition manuscript similarly used Peter to silence Mary. In the original text, both Peter and Mary ask Jesus questions. In the redacted scene, Peter asks both Mary's questions and his own. ${ }^{12}$ Here Mary is silenced, just as 1 Timothy specifies she should be.

If scribes silenced Jesus's mother by replacing her authority with Peter's, did they do the same thing to other women leaders? Of course, they did. For example, one fragment of the Thecla narrative says that Thecla asked Peter to send a priest to baptize a man that she herself had taught and converted. It says, "She wrote to the holy apostle Peter in Antioch and ... the priest came from Antioch and baptized the child's father and his whole household." 13 In another example, a Coptic scribe substituted Peter for Mariamne in the manuscript tradition of the Acts of Philip. As Ann Graham Brock says, "The replacement of Mary by Peter as Philip's companion in the Coptic version of the Acts of Philip eliminates the authoritative position she held in the original Greek text." 14

Later scribes, thus, employed a number of strategies to undermine the authority of early Christian women leaders. Art, however, is conservative. Despite that scribes often redacted the scene of Mary raising her arms as the prayer leader of the male apostles, this scene persisted in art. Early Christian art also preserves many images of Mary portrayed as a high priest or bishop.

\section{Mary in Art: High Priest and Bishop}

Art historian Alexei Lidov says that the gesture of raising hands "is interpreted in iconographic studies as a liturgical one," and he adds that the symbolic meaning of this gesture can be traced back "to the daily offering of the Evening Sacrifice in the Jerusalem Temple, the Old Testament prototype of the Eucharist."15 As noted above, many verses described priests raising their arms, and Psalm 141:2 explains, Let the raising of my hands be as the evening sacrifice. In the fourth century, Chrysostom similarly wrote, "I am raising up my hands as the Evening Sacrifice."16 In the West, the Ambrosian Rite specified that whoever celebrated the 
Eucharist was to raise their arms at the mystery, and even though the oldest manuscript of this rite is eighth century (like virtually all liturgical manuscripts ${ }^{17}$ ), its instruction is so similar to the reports in scripture and Chrysostom, that it seems highly likely to be a textual artifact preserved from an ancient Eucharistic liturgy. ${ }^{18}$ The intertextuality of the meaning of this gesture across both Jewish scripture and early Christian liturgical practice impacts how we understand depictions of Mary with her arms raised, in both text and art, in the early Christian era.

The Six Books scene of Mary raising her arms to lead the prayer of the twelve male apostles - the eleven plus Paul-is preserved in art that corresponds to the Six Books text. Despite the presence of Mary and Paul, until recently this iconography was misidentified as the ascension of Jesus-largely due to the fact that the Six Books text itself was censored to the extent that the scene was nearly lost from view. ${ }^{19}$ The bestknown example of this iconography is a beautiful full-page illumination bound with the Rabbula Gospels, which themselves were penned near Ancient Syria and dated 586. Suggesting the antiquity of this particular iconography, Jesus was painted with a halo that is not divided to represent his identity with the Trinity. After the fourth- and early fifth-century Trinitarian controversies, the divided halo became virtually obligatory for depictions of Jesus, and the Trinitarian halo is almost always seen on him in art dated after the early fifth century ${ }^{20}$ (see Fig. 4.1).

Consistent with the Six Books narrative about Mary's death, this illuminator depicted Mary as the focal point of the scene-she stands in the center with her arms raised. Additionally signifying her headship of the male apostles who stand on either side of her, Mary was painted taller than they. Her posture is erect and powerful, her gaze direct. Signifying her elevated spirituality, she is flanked by archangels, and only she, Jesus above her, and the angels, have halos. The men do not.

According to the Six Books narrative, when Mary had finished her prayer, "it thundered like the sound of wheels rolling over the surface of the sky." 21 Not long afterward, Jesus descended in a "chariot of light" with "wheels of fire" in order to resurrect his mother after she died and take her up to heaven. ${ }^{22}$ This illuminator thus painted Jesus's celestial chariot as an orb with flaming wheels spinning off reddish-orange fire. ${ }^{23}$ The Six Books also said angels held up his chariot, and the artist included four angels doing just that. ${ }^{24}$

Another key narrative element shown in this illumination, and which identifies it as the Six Books scene, is the apostle Paul. The Six Books 


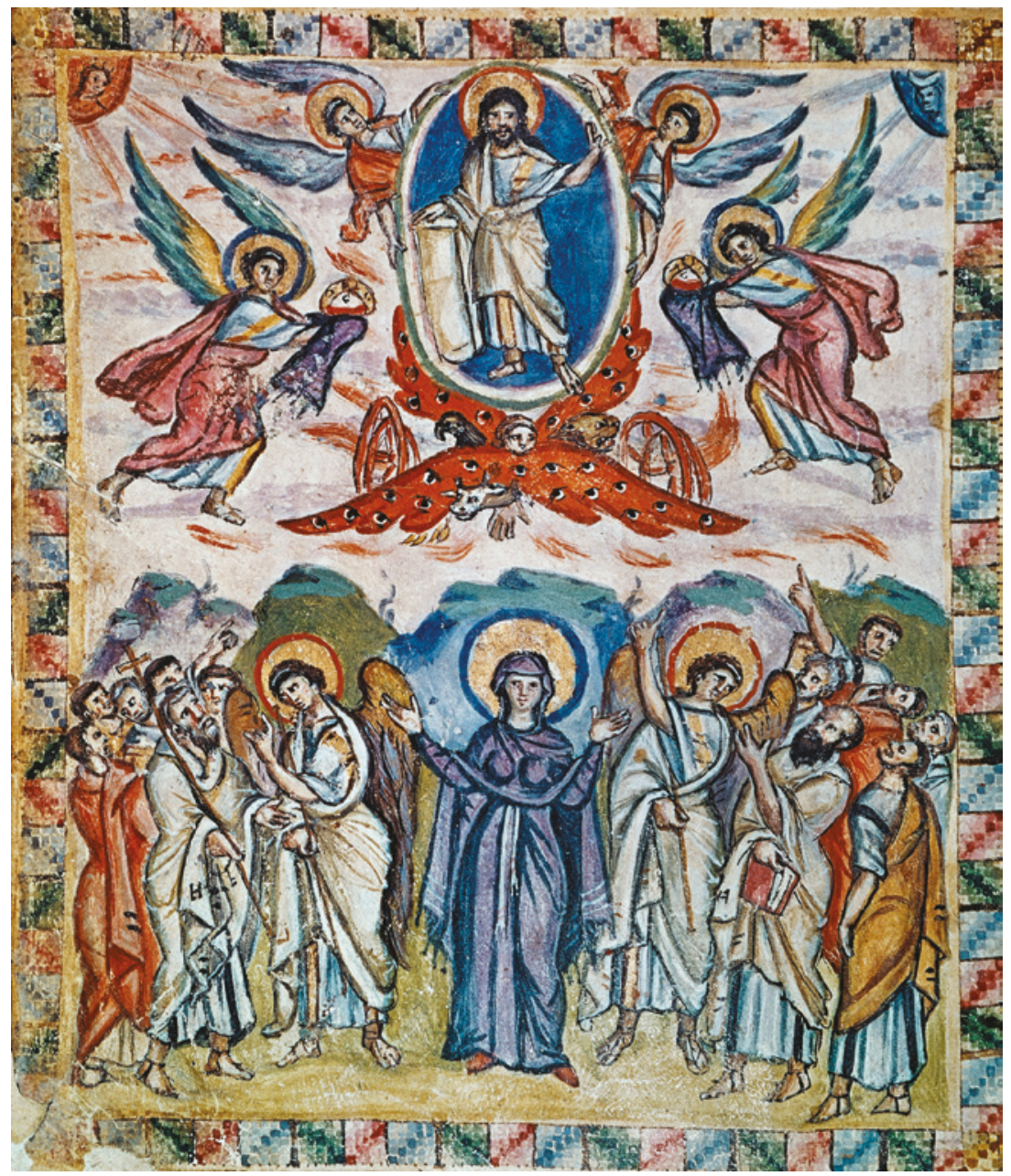

Fig. 4.1 Rabbula Gospels illumination of Mary. (C) Alinari Archives, Florence

author repeatedly said that the apostle Paul was one of the twelve male apostles who came to Mary. ${ }^{25}$ In the Rabbula Gospels illumination, Paul and Peter stand on either side of Mary and they themselves are painted larger than the other men. Peter is on the right and identifiable by his keys and thick bangs. Paul is on the left, identified by his large book and 
balding pate. Paul was described as bald in the Acts of Thecla 2-3, and artists used his baldness, as well as Peter's contrasting thick bangs, to distinguish them. For example, the sculptor of the famous fourth-century sarcophagus of Junius Bassus carved Paul entirely bald and Peter with curly bangs. ${ }^{26} \mathrm{~A}$ fourth-century gold glass from the catacombs of Rome similarly depicts PETRUS on the left with thick bangs, but on the right PAULUS is going bald ${ }^{27}$ (see Fig. 4.2).

Just as there is no controversy that the Six Books is about Mary the mother of Jesus, there is no controversy among art historians about this scene depicting her. The Rabbula Gospels illuminator in fact portrayed her with the same halo and dressed in the same dark blue outer garment called a maphorion in other scenes that clearly signify she is Mary, the mother of Jesus. For example, in another illumination, she is again portrayed in the midst of male apostles, this time with a dove and flames overhead in the traditional iconography of Pentecost, where Acts 1:14

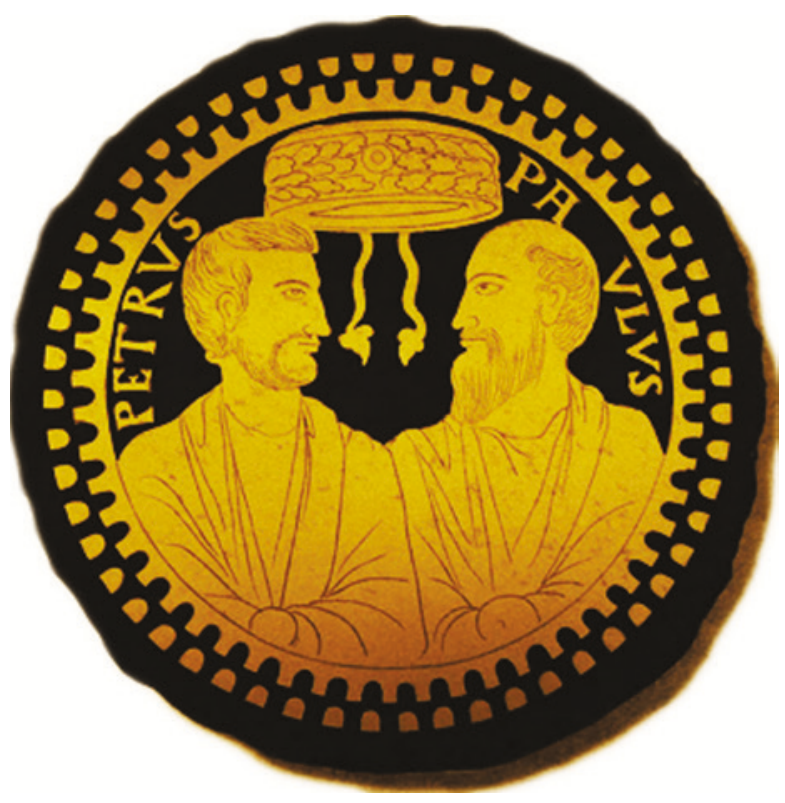

Fig. 4.2 Peter (left) and Paul (right). Gold glass ca. 350, catacombs in Rome. Perret, Catacombes de Rome, pl. 4:21.3 
identifies only "Mary the mother of Jesus" among the women in the upper room. ${ }^{28}$

A sixth-century painted reliquary box likewise illustrates that the arms-raised woman beneath Jesus was intended to represent his mother. This box was painted in or near Jerusalem for the pilgrim trade, and today it is in the Vatican Museum. Like the illuminator of the Rabbula Gospels, this painter included the scene with the arms-raised woman as one of several scenes, including the Nativity, that together identify her as the mother of Jesus ${ }^{29}$ (see Fig. 4.3).

The top right frame painted on this reliquary box is the Six Books scene with Mary wearing a black maphorion, standing arms-raised directly beneath her son, who is seen in an orb in the sky. She is again flanked by twelve men and a close inspection shows that here again a balding Paul is on the left and Peter, with bangs, is on the right. ${ }^{30}$ In this illustration, the men do not seem to have noticed Jesus descending; they stand quietly behind Mary, much as the Gospel of Bartholomew describes them standing behind Mary when she prays. ${ }^{31}$

The top left frame of this painted box depicts Mary in her black maphorion and another woman dressed in red walking toward the gated entrance to the shrine over Jesus's tomb beneath the Anastasis rotunda; her presence as one of the women at her son's tomb is consistent with her identification at the foot of the cross in John 19:25, and is a dominant motif in both art and text in the East. ${ }^{32}$ In the wide center frame, Mary, still in her black maphorion, stands on the left at the foot of the cross where she is usually seen in crucifixion iconography. The bottom right frame illustrates the baptism of Jesus, where, in the foreground on the right, two angels hold out Mary's black maphorion as if she had given them her outer garment to dry her son; and Mary herself stands watching on the left, behind John the Baptist, her hair in a bun on top of her head. Finally, the bottom left frame depicts the Nativity, with Mary resting in her black maphorion after giving birth. Her baby lies in a manger behind her and Joseph sits at her feet. The Nativity scene establishes without question that the woman in the black maphorion is Jesus's mother. ${ }^{33}$

The Six Books iconography of Mary with her arms raised in prayer beneath her son in the sky was popular very early, spreading around the Mediterranean. Sixth- and seventh-century artifacts depicting this scene include gold jewelry, ${ }^{34}$ a terracotta plaque, ${ }^{35}$ frescos in Coptic monastery buildings, ${ }^{36}$ ampoules that pilgrims brought home from Jerusalem, ${ }^{37}$ and more. Just as some scribes redacted their texts to reduce subtly the 


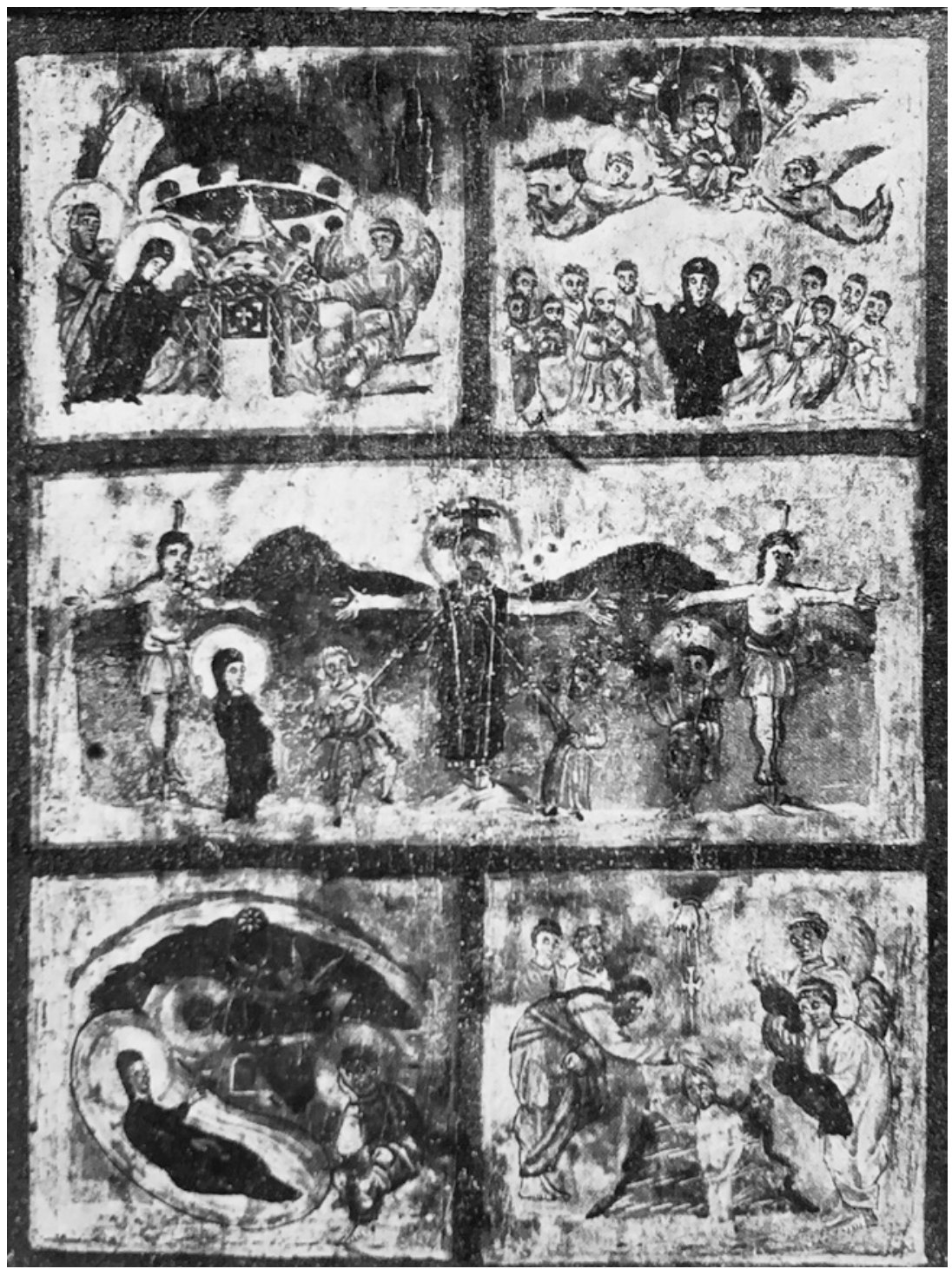

Fig. 4.3 Painted reliquary box ca. 500s, Jerusalem. Mary in five scenes. Top left: At Jesus' tomb. Top right: Prayer leader. Center: Crucifixion. Bottom right: Baptism. Bottom Left: Nativity. Grisar, Romische Kapelle, pl. 59 


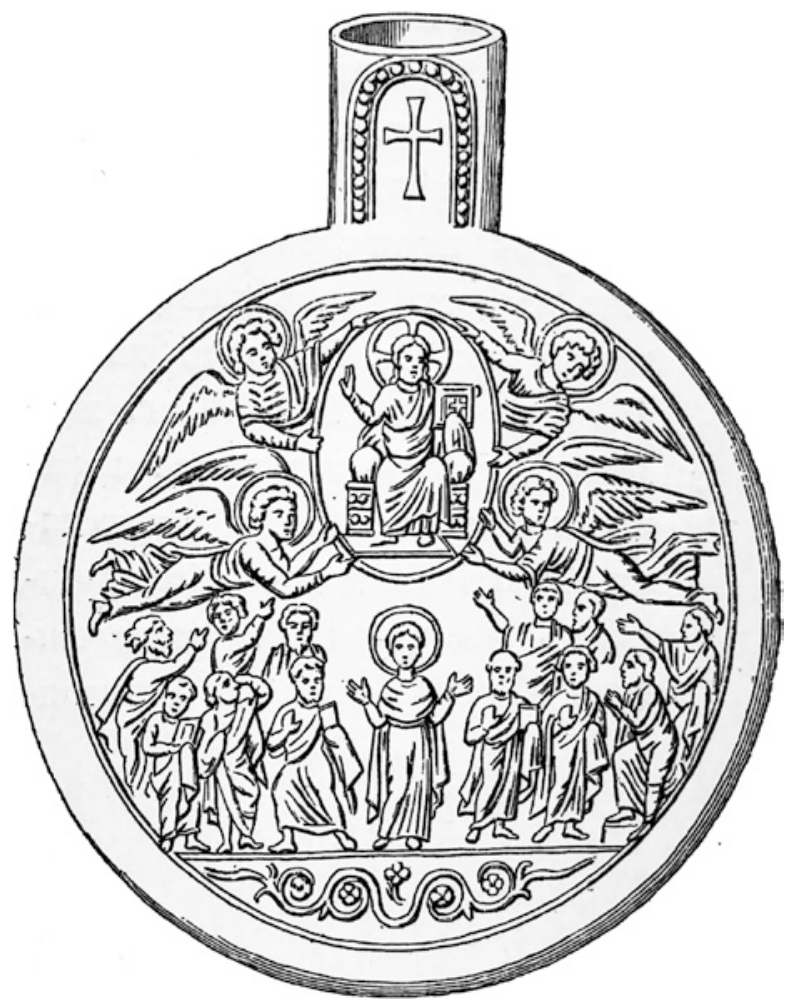

Fig. 4.4 Mary faces forward, arms-raised. Ampoule ca. 600s, Jerusalem. Monza Cathedral Treasury Museum. Garrucci, Storia, pl. 6:435.1

depiction of Mary's liturgical authority, some artists subtly changed Mary's bio-power in this scene. For example, in some cases instead of portraying Mary erect and confidently facing the viewer, with her hands high, artists depicted her semi-profile from the side, with her hands lowered, almost as if pleading instead of praying. Mary in this slightly hunched orante pose became known in the city of Rome as the Madonna advocata, for example, in her portrait on perhaps the oldest surviving icon, the sixth- to eighth-century Madonna of San Sisto. ${ }^{38}$ Both postures are seen on the small sixth- or seventh-century ampoules that pilgrims to Palestine brought back to Italy, but by far the most popular was Mary facing the front. ${ }^{39}$ In both cases, however, Mary remained the central focus directly beneath her son in the sky (see Figs. 4.4 and 4.5). 


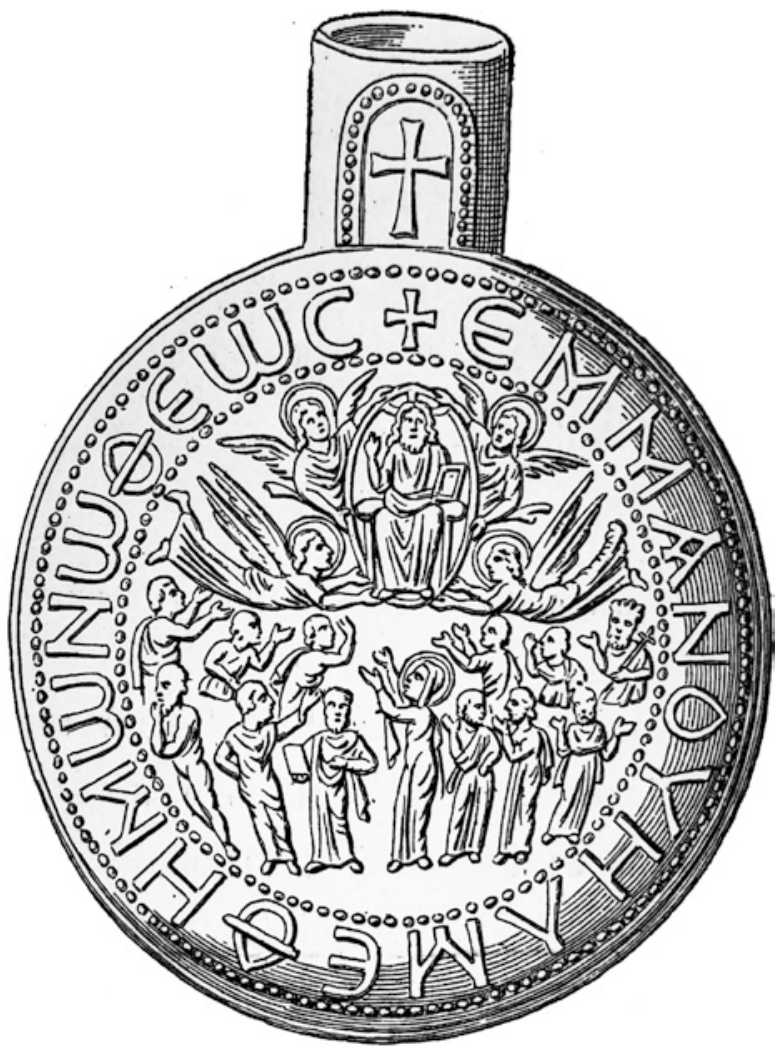

Fig. 4.5 Mary sideways, Madonna advocata. Garrucci, Storia, pl. 6:435.2

Various renderings of this iconography during the first millennium suggest the most critical and identifiable feature was the core verticality of Mary, arms-raised, placed directly beneath her son. This vertical pairing of mother and son in part may have been due to artists' familiarity with other Six Books scenes that depicted Mary raising her hands to pray to her son or to praise God when she was by herself, such as while visiting her son's tomb, while on the Mount of Olives, or while offering incense. ${ }^{40}$

Some artists depicted Mary in the middle of more than twelve men. For example, a sixth-century fresco in a Coptic monastery apse depicted her as the liturgical leader of thirteen. ${ }^{41} \mathrm{~A}$ mid-seventh-century mosaic in the altar apse of the Lateran Baptistery chapel of San Venantius in 
Rome depicts her as the leader of sixteen (Fig. 4.11). ${ }^{42}$ Some of the oldest examples depict her between only two men. One of the oldest ampoules depicted her between the Temple priest Zachariah and John the Baptist. ${ }^{43}$ The oldest surviving example decorating a church was carved on the Santa Sabina Basilica wood doors in Rome dated 420 to 430 , and this wood carving depicts her between Peter and Paul. ${ }^{44}$ Laura Marchiori notes that in subsidiary areas of early medieval churches, "The Virgin is commonly flanked by female saints" 45 _and some artists depicted Mary in this iconography flanked by women. For example, four women flank Mary in the tenth-century altar apse painting in the Santa Maria in Pallara monastery church in Rome. ${ }^{46}$ In an early fourth-century fresco in the Cubiculum of the Velata in the Priscilla Catacomb in Rome, two vignettes, both featuring a young woman, flank an arms-raised woman who may have represented Mary beneath a shepherd standing inside a circle. ${ }^{47}$ Marchiori notes a tradition of "funerary chapel decoration featuring the Virgin Mary in direct vertical placement with Christ, for whom she serves as primary intercessor." 48 Another early example of their vertical pairing in a funerary environment may be on a fourthcentury double tiered sarcophagus from the Christian cemetery outside Arles in ancient Gaul, today in the Arles Cathedral. This sculptor carved a boyish Jesus in the center of the top tier and an arms-raised woman standing directly beneath him in the center of the bottom tier. ${ }^{49}$ Scenes of Jesus performing miracles and healings flank them (see Fig. 4.6).

Demonstrating the strong memory of Mary in the arms-raised pose in Gaul even at this early date, the oldest surviving art to explicitly link Mary to the Jerusalem Temple was found sixty miles from Arles where the double sarcophagus is preserved. This stone plaque, along with other late fourth-century sarcophagi, is in a late fourth-century underground crypt, or hypogeum, beneath Sainte-Marie-Madeleine basilica in SaintMaximin La-Sainte-Baume. According to Michel Fixot, the hypogeum dates to $375 .{ }^{50}$ The sculptor of the plaque carved Mary with her hands raised. Inscribed above her head, she is identified as: MARIA VIRGO MINESTER DE TEMPULO GEROSALE, or, "Virgin Mary Minister of the Jerusalem Temple" (see Fig. 4.7).

This inscription is almost certainly a reference to a text like the Gospel of Bartholomew, which depicted Mary at the Temple altar, or the Protevangelium, which described Mary in the Jerusalem Temple as well as twice described her inside its Holy of Holies. ${ }^{51}$ Her portrayal with her arms raised on this plaque, as well as her title, Minister of the Jerusalem Temple, is consistent with her portrayal in the Six Books as a liturgical 


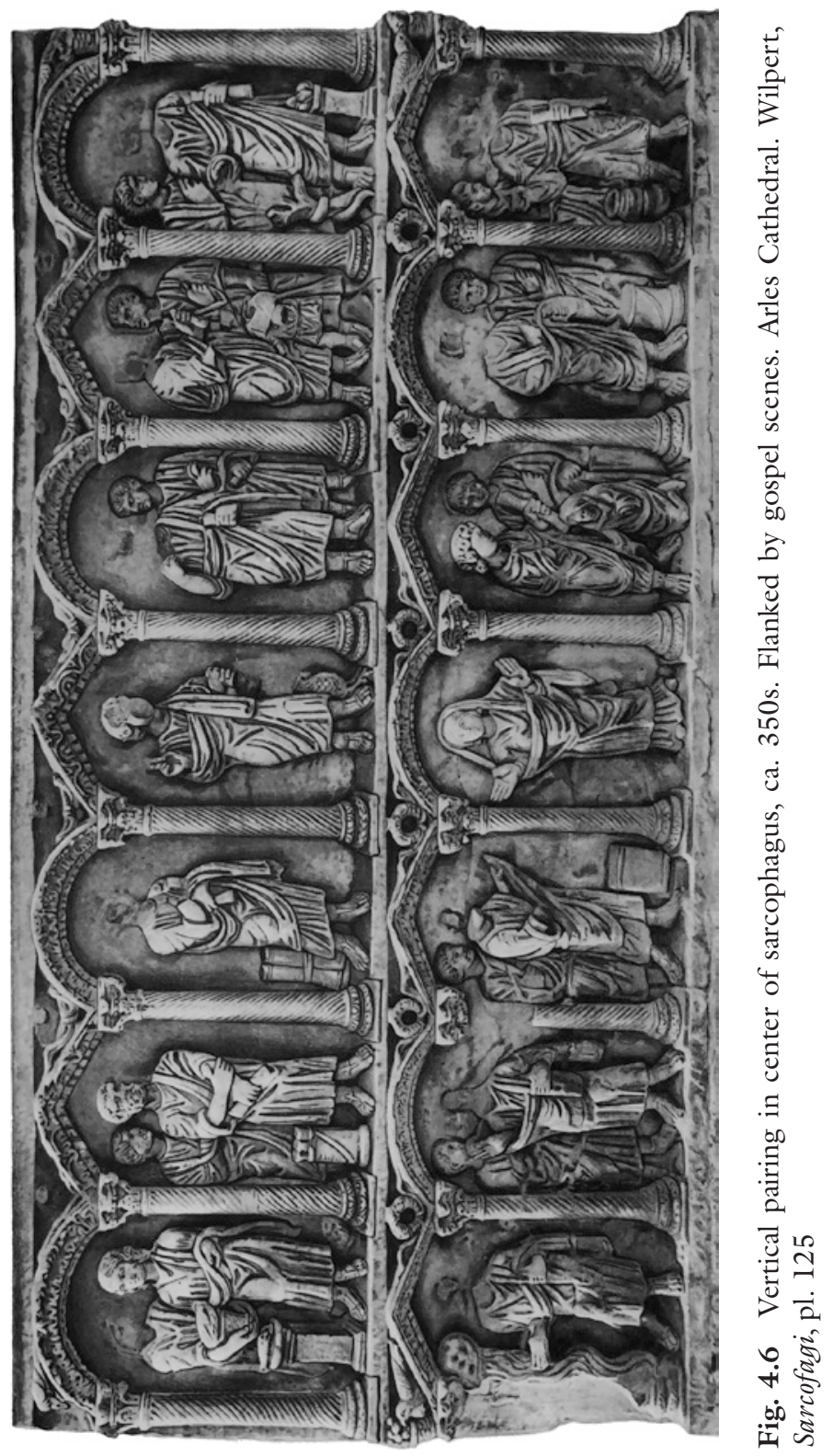


Fig. 4.7 MARIA

VIRGO MINESTER

DE TEMPULO

GEROSALE. Stone

plaque in hypogeum

ca. 375. Sainte-Marie-

Madeleine Basilica

crypt, Saint-Maximin

La-Sainte-Baume,

France. Le Blant,

Sarcophages chrétiens de

la Gaule, pl. 57.1

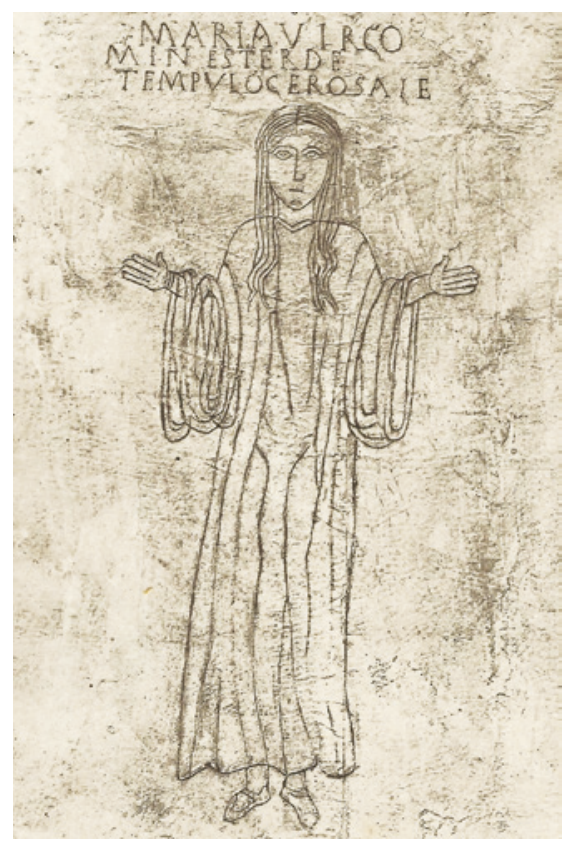

leader within the scriptural memory of the Temple priesthood-raising her arms to bless people, lead the prayer, and praise God. The clear association with the Temple reminds us that Lidov says that the gesture of raising hands "is interpreted in iconographic studies as a liturgical one," and that the symbolic meaning of this gesture can be traced back "to the daily offering of the Evening Sacrifice in the Jerusalem Temple, the Old Testament prototype of the Eucharist." 52 As noted above, many verses described priests raising their arms, and Psalm 141:2 explains, Let the raising of my hands be as the evening sacrifice. In the fourth century also, Chrysostom wrote, "I am raising up my hands as the Evening Sacrifice." ${ }^{53}$ In the West, where we find this plaque, the Ambrosian Rite specified that whoever celebrated the Eucharist was to raise their arms at the mystery, which, given the other sources, may also be related to ancient practice. ${ }^{54}$ This intertextuality impacts our understanding of how fourth-century Christians likely saw this portrait of Mary. 


\section{Mary with the Episcopal Pallium}

The oldest surviving uncontroversial portrayal in art of a Christian minister officiating at the Eucharist with arms raised high like Mary is depicted in this fourth-century plaque may be an eleventh-century wall painting of Pope Clement. This painting was discovered in the mid$1800 \mathrm{~s}$ in the underground Basilica of Old Saint Clement's. ${ }^{55}$ Pope Clement is depicted with his arms raised, a chalice and a paten of bread on the cloth-covered altar table behind him. The open gospel book, the symbol of a bishop, is in front of him. Clement holds the Eucharistic cloth or handkerchief, which in the West from the ninth century was called the maniple. ${ }^{56}$ Most significantly, he wears the episcopal palliumthe long white strip of cloth with a cross on it that was to be worn only when officiating at the Eucharist-See Fig. 4.8.

Fig. 4.8 Pope Clement officiates the Eucharist at the altar. Wall painting ca. 1000, Basilica of Old Saint Clement, Rome. Wilpert, Römischen Mosaiken, pl. 240

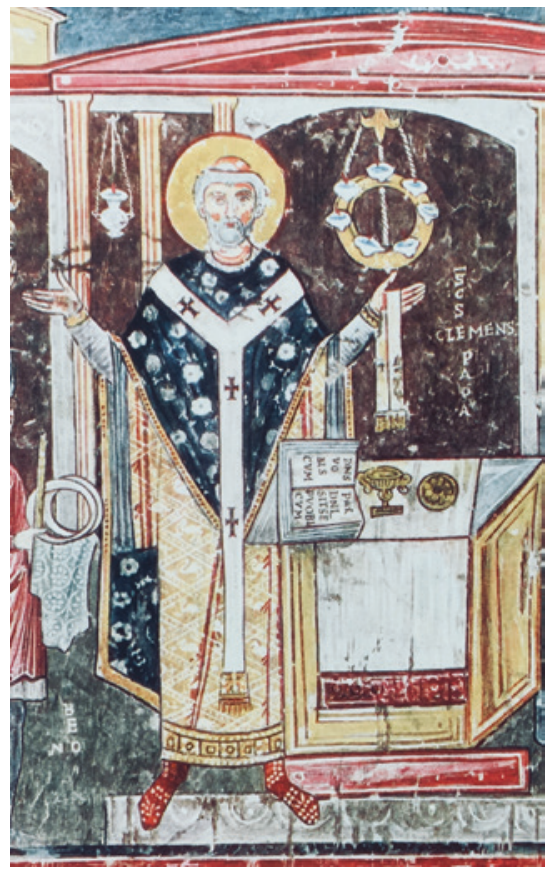


In the early church, clergy wore the same apparel as the laity, apparel retained by custom over the centuries. Today this lay garb looks rather special. The episcopal pallium, such as Pope Clement wears in the wall painting, eventually became the distinctive episcopal symbol of the bishop's vestment in the West. ${ }^{57}$ Pope Gregory the Great (r. 590-604) reportedly gave the pallium only to the bishops of the most important cities, such as Ravenna and Milan, and he prohibited its use except during the Eucharist. ${ }^{58}$ Consistent with Mary portrayed in texts as a high priest or bishop, portraits of Mary wearing the episcopal pallium are as old as any that have survived of a man wearing it.

The oldest surviving uncontroversial depiction in art of a male bishop wearing a pallium is mid-sixth century, the same time that we first see Mary wearing it. In this art, this ancient episcopal pallium looks essentially the same as the modern, a long strip of fine white cloth with a black cross on it. Five mosaics in three basilicas depict people wearing this pallium. Two mosaics portray male bishops, two portray Mary, and one portrays Elizabeth, the mother of John the Baptist. All are in the altar apse, where the Eucharist was celebrated below, accentuating the liturgical significance of the pallium.

All three basilicas were completed with many of the same design features. Each was most likely constructed during the reign of Emperor Justinian and Empress Theodora, who dedicated many churches to Mary. ${ }^{59}$ The two basilicas with the men are in Ravenna, and the one with Mary and Elizabeth is almost directly east, perhaps a day's sail on the other side of the Adriatic.

Bishop Maximianus of Ravenna was depicted wearing an episcopal pallium standing next to the Emperor Justinian in a mosaic side panel in the apse of the Basilica of San Vitale in Ravenna, completed around 547.60 The martyr Bishop Apollinaris was depicted arms-raised while wearing an episcopal pallium in the center of the altar apse in the Basilica of Sant'Apollinare in Classe near Ravenna, completed around 549. ${ }^{61}$ Within approximately the same decade, Mary was depicted twice and Elizabeth was depicted once wearing the episcopal pallium in the Euphrasiana Basilica in Poreč, Croatia, a church dedicated to Mary. ${ }^{62}$ These mosaics of Mary and Elizabeth probably were completed during the reign of Bishop Euphrasius (543-554), but could be as early as $526 .{ }^{63}$

Mary's most visible placement in the Euphrasiana Basilica was in the center of the altar apse, directly above the episcopal throne behind the altar. Here the cross of her episcopal pallium is seen just below the hem of her maphorion. ${ }^{64}$ (see Fig. 4.9a, b). 
(a)

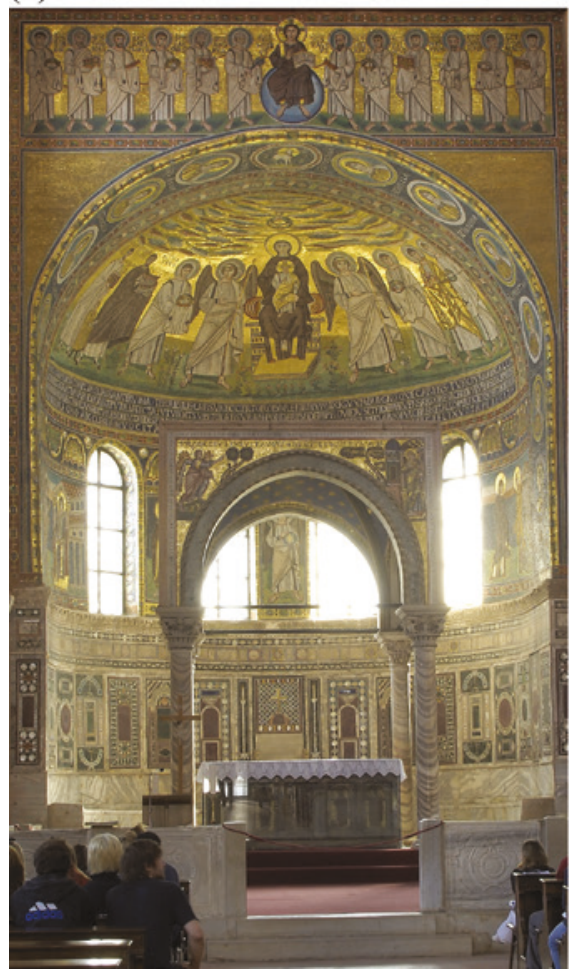

(b)

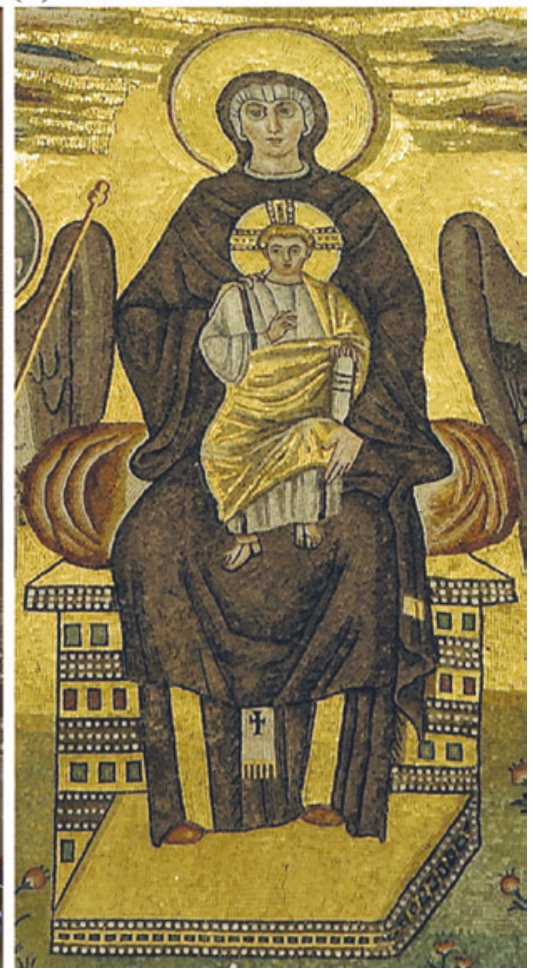

Fig. 4.9 a Euphrasiana Basilica ca. 550, Poreč, Croatia. b Mary wears episcopal pallium. (C) Iberfoto/Alinari Archives

An early design feature of this basilica's apse is consistent with Mary's association with women. Her portrait in the altar apse, wearing the episcopal pallium, is framed by round portraits of twelve women, while at the very top, Jesus is flanked by twelve men. Many of the twelve women portrayed around Mary-Thecla, Eugenia, Euphemia, Valeria, Perpetua, Susanna, Justina, Agatha, Agnes, Cecilia, Basilissa, and Felicitas ${ }^{65}$-still today are known as apostles and other leaders in the early Jesus movements. It seems likely that many more long narratives about these women - teaching, preaching, evangelizing, converting, and baptizingstill existed in the middle of the sixth century. Mary wearing the episcopal pallium, as well as these twelve women in the apse, may have been used to guarantee such roles for other women of this era. ${ }^{66}$ 
The second mosaic that portrayed Mary wearing an episcopal pallium in the Euphrasiana Basilica is on the wall to the right of the altar. Here, Elizabeth, the mother of John the Baptist, also has the episcopal pallium. This mosaic is of the Visitation in Luke 1:39-56, where Mary visited her relative Elizabeth. Each is depicted as being pregnant and wearing the episcopal pallium hanging from beneath her coat. ${ }^{67}$ The representation of Elizabeth, as well as Mary, wearing an episcopal pallium, is consistent with Vernon K. Robbins' recent analysis of Luke's portrayal of Elizabeth as a priest. For example, Luke 1:5 specifies Elizabeth's priestly lineage through the daughters of Aaron. Luke 1:42 says that at the Visitation the Holy Spirit filled Elizabeth and in a loud voice she cried out two blessings, one for Mary and one for the child in her womb. Per Sirach 50:20-21, blessing is what a Temple priest did, and Robbins concludes, "Elizabeth, a daughter of Aaron, speaks to Mary like a priest" ${ }^{\text {"6 }}$ (see Fig. 4.10).

Mary and Elizabeth were each depicted with an episcopal pallium hanging down in front, from beneath their coats, whereas the two male bishops of Ravenna were depicted with theirs hanging off their left shoulder. Notably, Pope Clement officiating at the Eucharist was also depicted with his pallium hanging down in front. Most likely differences in how the episcopal pallium was worn reflected gender differences, or differences in styles between various communities.

In the past, the interpretation that Mary was depicted with an episcopal pallium was not popular among all scholars, some of whom have tried to explain away that depiction in these mosaics. ${ }^{69}$ Recently, however, other scholars have taken the lead in identifying Mary's apparel as what it looks like. Mary M. Schaefer calls Mary's pallium in these mosaics "the unmistakable archiepiscopal pallium."70 Alexei Lidov calls it a symbol of Mary's priesthood. ${ }^{71}$ Ivan Foletti argues that during a time when ordained women were under attack by some men in the hierarchy, portraits of the mother of Jesus as an ordained woman served to position her as the protector and guarantor of women clergy. ${ }^{72}$

The understanding that Mary was a bishop or high priest, like the Six Books, Protevangelium, and Gospel of Bartholomew portrayed her, was apparently influential around the Mediterranean, but not without controversy even then. For example, during the same century that the mosaic depicting Mary as a bishop was installed in the Euphrasiana Basilica, John of Ephesus (ca. 507-588), a famous Syriac writer in Palestine, wrote a morality tale as a warning for Christians who apparently believed that Mary sat on a bishop's throne and ordained priests. ${ }^{73}$ 


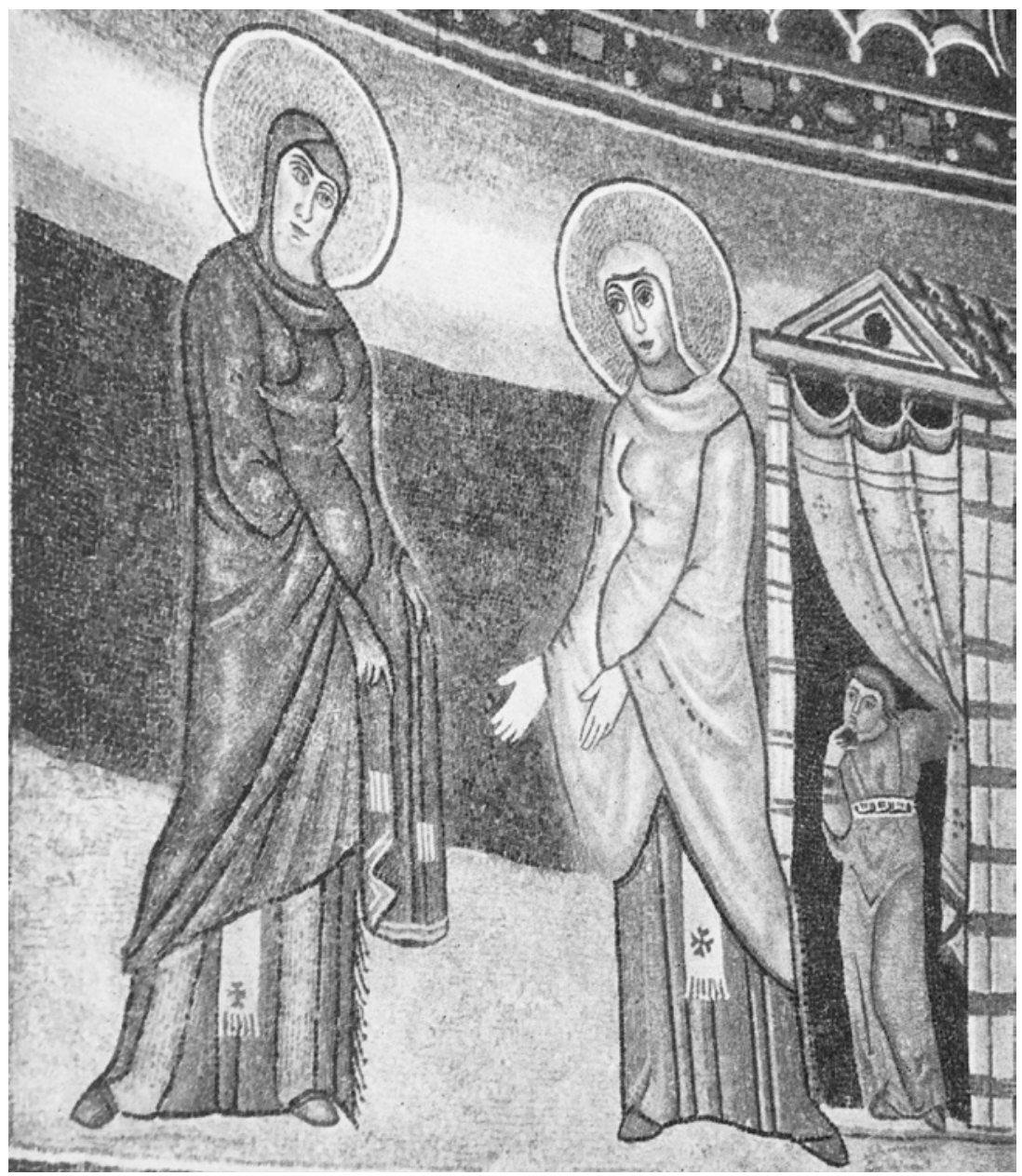

Fig. 4.10 The Visitation. Mary (left) and Elizabeth (right) wear the episcopal pallium. Mosaic ca. 550. Euphrasiana Basilica, Poreč, Croatia. Wilpert, Römischen Mosaiken, fig. 313

Nonetheless, the tradition of Mary's role as a bishop who had at least as much, if not more, authority than male bishops seems to have remained steady in some communities, including among those today considered the most orthodox. For example, half a century after John of Ephesus died, Pope John IV (r. 640-642) began installing a mosaic 
that reprised the vertical Six Books composition in the altar apse of the Lateran Baptistery Chapel of San Venantius in Rome, a mosaic ultimately completed by Pope Theodore I (642-649). ${ }^{74}$ In this mosaic, Mary was placed directly above the actual altar. The laity in the nave would have seen her as the Eucharistic leader of sixteen men. Paul (balding) and Peter (bangs) were next to her, then several holy men, and finally bishops who wore the episcopal pallium with a black cross. Mary herself wore an episcopal pallium with a red cross and she also wore red shoes. Both the pallium and the shoes are still insignia of the bishop of Rome, the pope $\mathrm{p}^{75}$ (see Fig. 4.1la, and for detail, Fig. 4.11b).

Schaef er calls Mary in this mosaic Maria archiepiscopa. ${ }^{76}$ From the perspective of the laity in the nave, Mary was seen above and behind the altar as the chief officiant of the Eucharist. For the laity, Mary's Eucharistic privilege would be signified by her raised arms, her episcopal pallium with its red cross, and by the subordinate position of the bishops who flanked her, as well as her own central position during the rite as mediator with the divine, standing directly beneath Christ, who himself appears to be blessing and authorizing her.

Today not everyone in the Vatican is as comfortable with this mosaic as Popes John IV and Theodore I were almost 1500 years ago. Today this mosaic of Mary is a visual metaphor for the trajectory of redaction around the markers of her liturgical authority. In a city where virtually every other ancient mosaic is on display for pilgrims and tourists, today a huge baroque altarpiece hides this mosaic of Mary. This altarpiece not only hides the episcopal Mary, it features a demure portrait of Mary holding her baby, and thus operates both to conceal and to replace the original image of Mary. From the back of the nave, one can see Jesus's head above the top of this altarpiece, and one can see the men on either side of it-but the massive piece of furniture completely hides Mary. Her image is so well concealed that it took me multiple visits to this chapel searching for her before I finally noticed Christ's head above the altarpiece, and realized that Mary was hidden behind it. ${ }^{77}$

In 1916 the Holy Office forbade depictions of Mary dressed in priestly vestments, and quite likely that was when the huge altarpiece was installed. ${ }^{78}$ Perhaps the red tesserae of the cross on Mary's white pallium were removed at the same time. In any case, sometime before 1899 , Giovanni Battista de Rossi painted an image of the mosaic with a full red cross on Mary's pallium. All that remains of the red cross today are a few red tesserae. White tesserae have been installed where the rest once were. ${ }^{79}$

Iconography of Mary portrayed as a bishop persisted for several centuries around the Mediterranean. ${ }^{80}$ The Saint Demetrios nave mosaics 
(a)

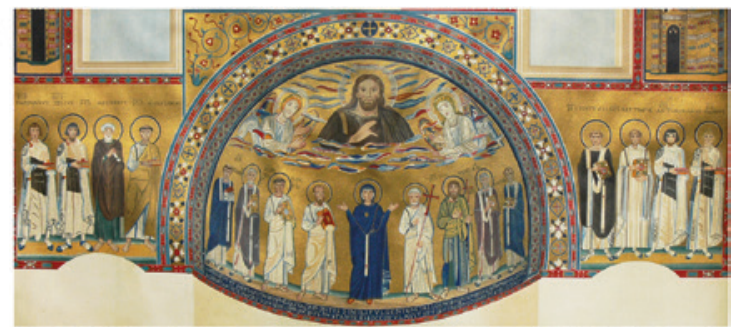

(b)
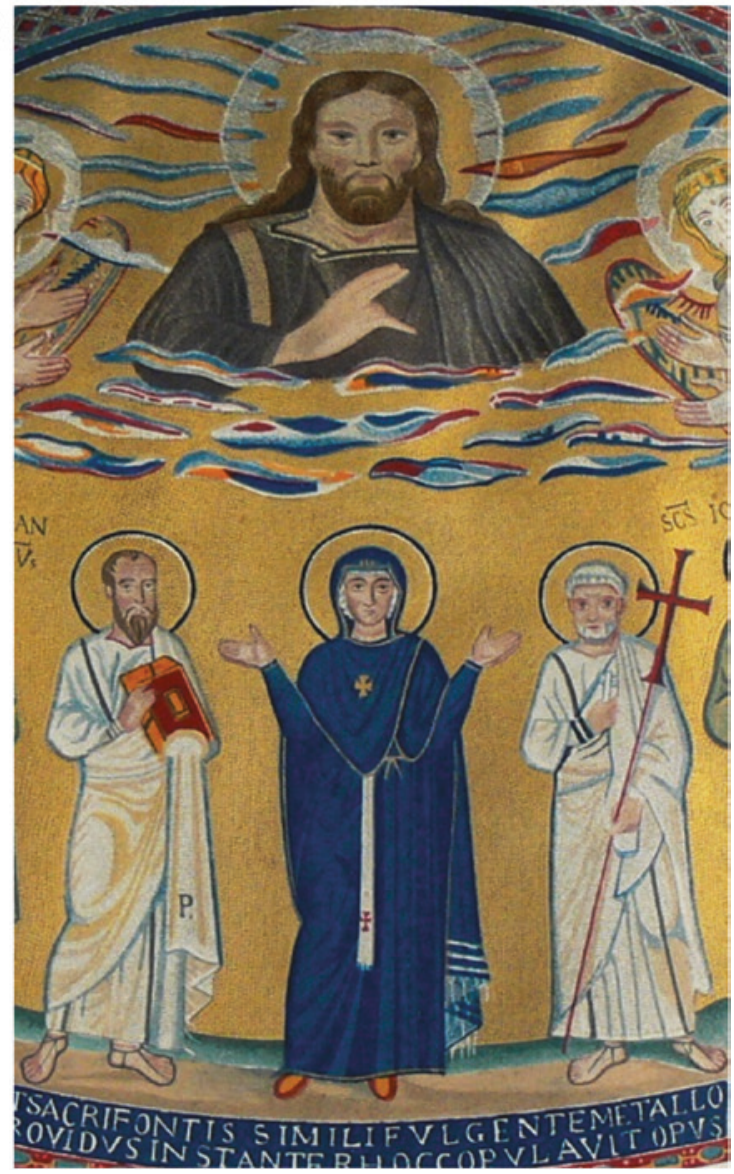

Fig. 4.11 a Mosaics, ca. 650, San Venantius Chapel, Lateran Baptistery, Rome. b Mary wears episcopal pallium with red cross, flanked by Paul and Peter. 1890s painting. De Rossi, Musaici cristiani, pl. "Abside dell'oratorio di S. Venanzio" 
in Thessaloniki, which were destroyed by fire in 1917, portrayed Mary wearing what appears to have been a type of pallium. These mosaics were probably installed between the late fifth and seventh centuries, but during Iconoclasm they were covered with plaster and uncovered again only in 1907. Fortunately photos, though not very distinct, as well as watercolors were made of them before the fire. ${ }^{81}$ In one photo, Mary is seated holding her son with a long cloth extending downwards in front of her skirt with three stripes on the end. ${ }^{82}$ In a second photo, Mary is portrayed as a side-view orante with a long white cloth hanging from beneath her maphorion. ${ }^{83}$

Another artifact, an ivory icon from Egypt or Palestine, carbon dated between 720 and 970, provides an excellent example of how this art was interpreted in some communities. ${ }^{84}$ Its sculptor carved it in the Six Books iconography-Mary, arms-raised, directly beneath Jesus inside an orb, with men beside her. Further signifying her elevated liturgical position, a long festival pallium, or omophorion (the comparable insignia in the East), with many crosses on it hangs from beneath her short chasuble-like upper garment. Six men are present-the sculptor may

Fig. 4.12 Mary as bishop of bishops. Ivory icon from Egypt or Palestine, dated 720 to 970 . Metropolitan Museum of Art, CCO

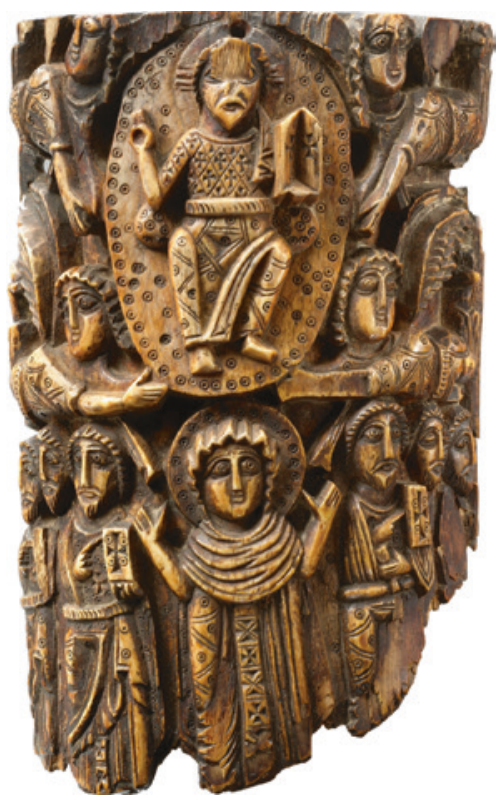


have carved more men around the lost back half-and each man carries a large gospel book, the symbol of the bishop, and also wears a pallium hanging from beneath his coat, hanging almost exactly the same as Mary and Elizabeth's were depicted hanging from beneath their coats in the mosaics of the Euphrasiana Basilica ${ }^{85}$ (see Fig. 4.12).

An example in the West of Mary wearing a similar long white strip of cloth with many crosses on it, in this case hanging from beneath her maphorion on her left side, was originally in the Ravenna Cathedral's altar apse and dated 1112. Today it is in the Archbishop's Museum in Ravenna. ${ }^{86}$ Even after that late date, for several centuries, in both East and West, occasionally Mary was depicted wearing liturgical insignia or garments, suggesting that familiarity with the motif of her priesthood continued in some communities. ${ }^{87}$

\section{Mary with the Cloth of the Eucharistic Officiant}

Another insignia of the Eucharistic officiant is what Lidov calls the "Eucharistic handkerchief," a narrow white cloth, sometimes plain, sometimes fringed, sometimes with thin embroidered stripes at the bottom, to be worn only during the Mass. Lidov treats this cloth as an important symbol in art of the priesthood of Mary. ${ }^{88}$ The significance of this cloth in the West is apparent in the eleventh-century wall painting of Pope Clement in Fig. 4.8, which depicts Clement holding the cloth while performing the Mass.

From the first time we see it in fifth-century church art, this cloth almost certainly represented authority and leadership. Just like the episcopal pallium was probably borrowed from consular garb, this doubled cloth was called the mappa and outside the church was associated with the authority of the consul or emperor. ${ }^{89}$ When used by someone in association with the altar or the altar area, the cloth represented their authority in that environment. One of the first instances in Christian art where this cloth is seen as a distinctly separate cloth is on a fifthcentury ivory diptych from Italy or Gaul, where four men, apparently the four evangelists, are depicted holding the cloth along with a large book that appears to have the four symbols of the evangelists in each corner, that is, a gospel book. ${ }^{90}$ A century later the cloth is seen again in the hands of the four evangelists on the front of the mid-sixth-century ivory throne of Bishop Maximianus of Ravenna (r. 546-556), which depicts all four evangelists, three of whom have the fringed cloth over their hand 
holding their book, along with a fourth who holds his book under his arm, with the fringed cloth doubled in his hand. ${ }^{91}$ As demonstrated by the book sculpted on the altar below the hanging lamp in Fig. 2.8, as well as by the open book with Pope Clement in Fig. 4.8, the gospel book was associated with the altar during the liturgy. ${ }^{92}$ Indicating the use of this cloth to cover the hand when touching other liturgical objects as well, another ivory plaque on the throne portrays Jesus between two men (one balding and one with bangs), each of whom holds a platter, or paten, with a cloth draped over his hand; one platter is laden with bread and the other with fish. ${ }^{93}$

Around the ninth century in the West, this narrow strip of white cloth, sometimes fringed and sometimes with embroidered stripes at the end, became known as the maniple, the privilege of a Eucharistic officiant, by then mostly male. In the East, according to Lidov, "An analogue of the western maniple was the so-called enchirion (literally "handy") a white handkerchief hanging at the girdle of an archpriest, later called epigonation." " By the time of Clement's painting, the cloth already had been in use for several centuries in some churches in both East and West in one form or another, held in the hand, as Clement demonstrates, or hanging from the girdle. ${ }^{95}$ Because of its different names in both East and West-and art depicting women using it was made in both East and West-I refer to it simply as the Eucharistic cloth.

Lidov says that this Eucharistic cloth, or "Eucharistic handkerchief" as he calls it, "carefully introduced the theme of the participation of the Virgin in the Eucharistic sacrifice and of Her priesthood."96 Mary was portrayed with the Eucharistic cloth relatively frequently around the Mediterranean, sometimes lifting it with her left hand, like Pope Clement at the altar table in the eleventh century, but also, with her arms raised and the cloth hanging from the girdle at her waist. Often she was portrayed in the altar apse, which, given her placement above and behind the altar, accentuated her sacrificial role. Her portrayal with the cloth in the altar apse is consistent with her portrayal with the episcopal pallium in the altar apses of the mid-sixth-century Euphrasiana Basilica and the mid-seventh-century Lateran baptistery chapel in Rome. Both vestments were to be worn only during the performance of the Eucharist itself.

In Rome, the oldest portrait of Mary holding the Eucharistic cloth may be a wall painting, variously dated late fifth to sixth century, in what today 
is known as the church of Maria Antiqua in Rome, but what originally was a palace anteroom. Mary is seen seated, holding her son on her lap, and holding up the white cloth, a small black cross visible on the fabric. ${ }^{97}$ She is similarly painted holding the cloth in a mid-sixth-century wall painting in the Commodilla Catacomb in Rome. In this catacomb portrait, the widow Turtura stands next to her and is depicted using another white fringed cloth to hold what appears to be a book or a platter/paten. ${ }^{98}$

A Coptic apse painting of Mary in Chapel 17 of the Bawit Monastery may be the oldest surviving art portraying her with both arms raised, the cloth hanging from a girdle at her waist. This portrait of Mary was probably painted sometime between the fifth and seventh centuries, although potentially even the fourth century since renovations began then. The painter portrayed Mary in the middle of thirteen men, and as usual standing directly below a young beardless Jesus in the sky, who himself is inside a circle, which is on a mass of scarlet flames. In this Six Books scene in the eastern apse, the leadership symbolism associated with the cloth hanging from Mary's girdle evokes her liturgical authority ${ }^{99}$ (see Fig. 4.13a for the apse and Fig. 4.13b for detail of Mary).

(a)

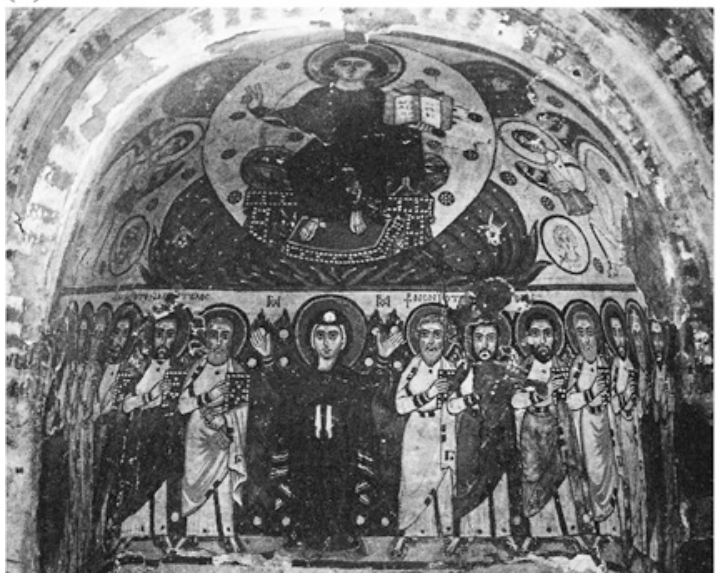

(b)

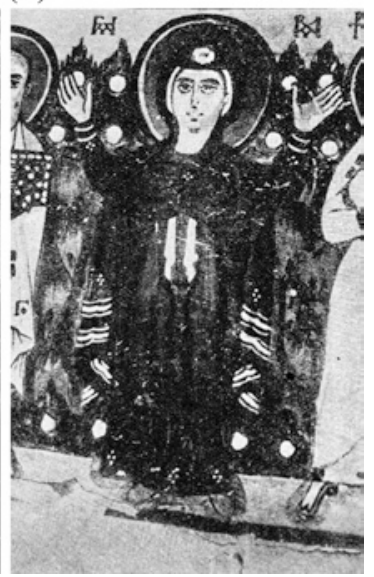

Fig. 4.13 a Bawit Monastery fresco. b Mary wears cloth. Clédat, Monastère, pl. 40,41 
A sixth-century altar apse mosaic in a church dedicated to Mary in Livadia, Cyprus, is fragmentary today, but it portrayed Mary standing on a low platform against a gold tesserae background flanked only by two angels, her arms raised and two white strips of cloth hanging from beneath her dark blue maphorion. ${ }^{100}$ Richard Maguire suggests that her portrait in this mosaic is much like her portrayal in the Rabbula Gospels illumination (Fig. 4.1). ${ }^{101}$ Demonstrating the longevity and popularity of this iconography for Mary, both Arthur Megaw, who first studied the Livadia mosaic when a layer of plaster was removed from it, as well as Robin Cormack, favorably compare its sixth-century iconography to that of the eleventh-century altar apse mosaic in Holy Sophia Cathedral in Kiev, which depicts Mary, again standing by herself with her arms raised, wearing the white cloth, shorter, doubled over her belt. ${ }^{102}$ This mosaic in Kiev also closely resembles the top right painted frame of Mary, arms-raised, flanked by the twelve men on the early sixth-century painted reliquary box. This painter similarly executed two short white strips at Mary's girdle, seen upon close inspection (Fig. 4.3). The Livadia mosaic is also similar to the mosaic of Mary in the altar apse in the Cefalù Cathedral in Sicily, which the Normans built seven hundred years later, in 1240. In its apse, Jesus and Mary appear in the core vertical composition, with Jesus above as a huge bearded Pantocrator. Mary stands below him flanked by four angels, her arms raised, two red-striped ends of a white cloth hanging from her girdle (see Fig. 4.14a, b for detail).

The sixth-century altar apse mosaic of Mary in the famous Koimesis, or Dormition, church in Nicaea was reportedly restored in the ninth century after Iconoclasm ended. ${ }^{103}$ A photo taken of this apse mosaic before the church burned in 1922 illustrates Mary holding her son while also holding the white fringed cloth in almost the same gesture that Pope Clement was painted holding it while performing the Eucharist. The sixth- or seventh-century altar apse mosaic in the Virgin Angeloktisti Church in Kition, Cyprus, depicts Mary holding her son with two narrow strips of fringed cloth hanging from her girdle. ${ }^{104}$ The late ninthcentury mosaic in the altar apse of the Hagia Sophia in Constantinople was perhaps the most prominent placement in Christendom. It depicts Mary seated and holding her son, the fringed cloth again in her hand. ${ }^{105}$ 
(a)

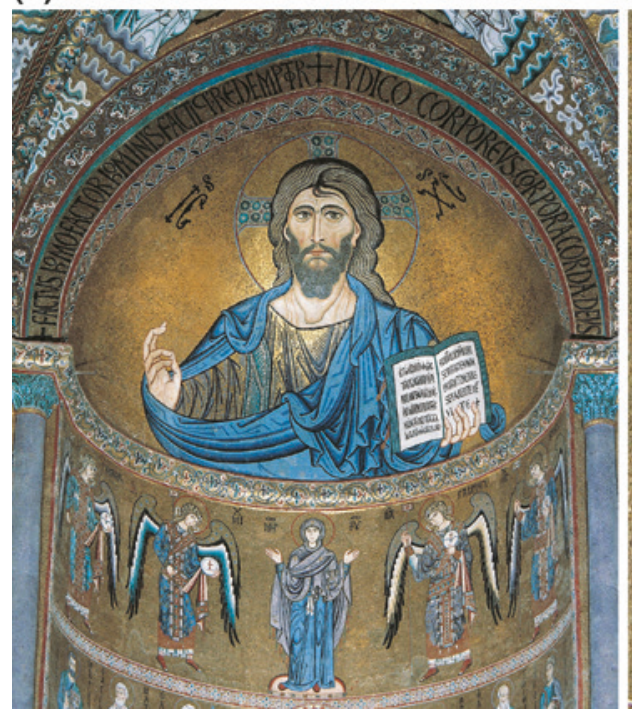

(b)

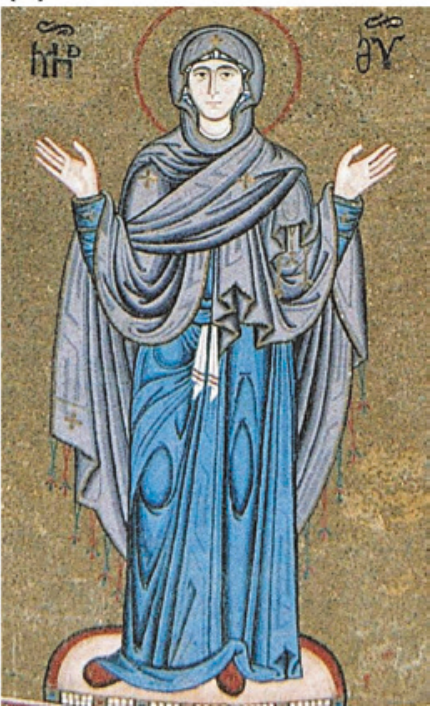

Fig. 4.14 a Altar apse mosaics ca. 1240, Cefalù Cathedral, Sicily. b Mary wears the cloth. (C) DeA Picture Library, licensed by Alinari

In the West, fifty years before the Hagia Sophia apse mosaic was completed, Pope Paschal (r. 818-822) in Rome oversaw the design of a mosaic in the altar apse of Santa Maria in Domnica, which portrays him with a rectangular halo (indicating he was alive when his portrait was made) and kneeling at Mary's feet. ${ }^{106}$ Mary holds both her infant son and the fringed Eucharistic cloth embroidered with two thin red stripes. By this date, the cloth had become known in the West as the maniple, an important clerical privilege and permanent element of the liturgical vestments of a bishop. ${ }^{107}$ From the perspective of the laity in the nave, this mosaic portrait of Mary holding both her son and the fringed maniple created an inescapable visual analogy. Above the altar table, Mary held the maniple and offered her son, while below her officiants with the same maniple stood offering his symbolic body and blood ${ }^{108}$ (see Fig. 4.15). 


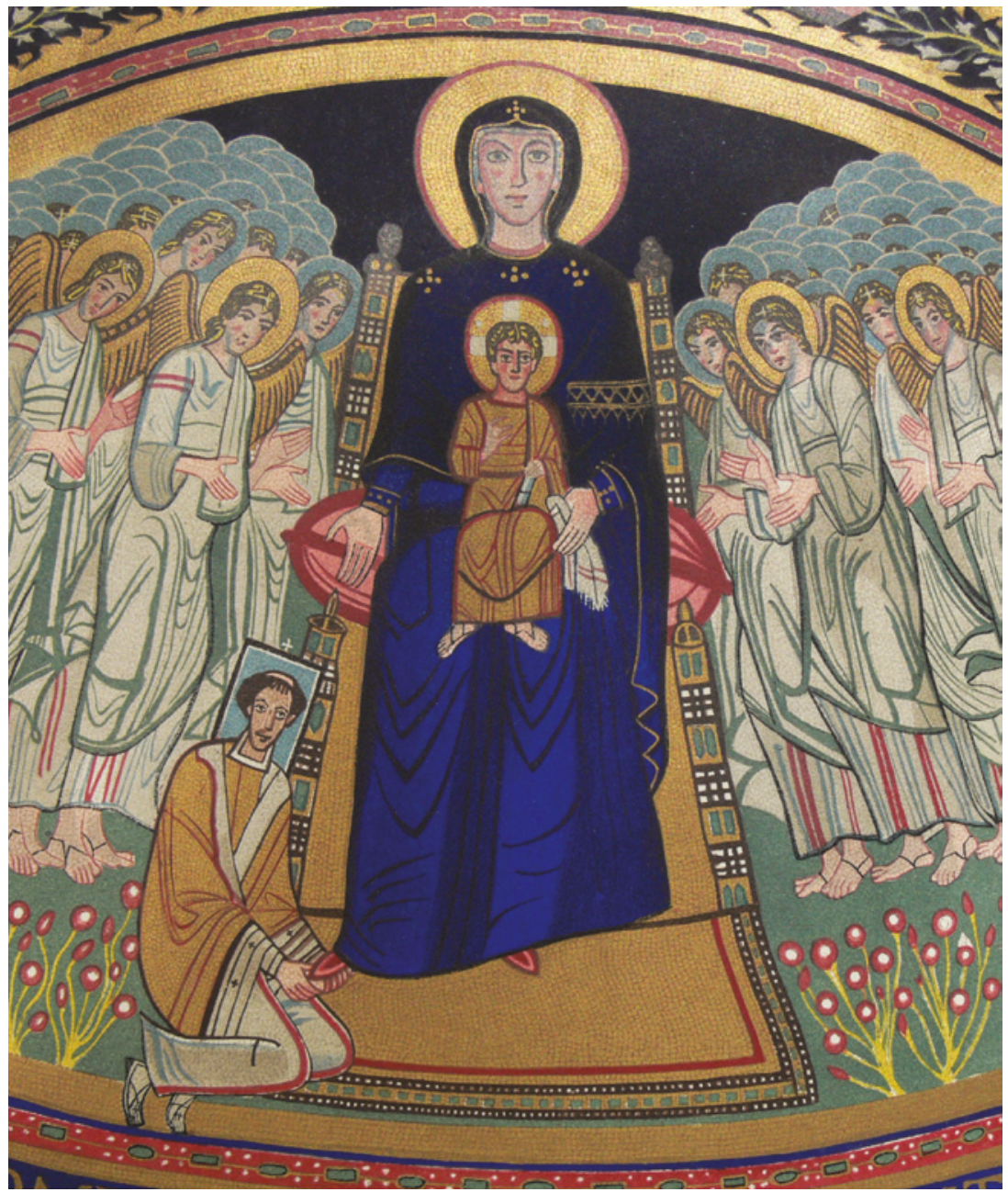

Fig. 4.15 Mary holds the cloth. Altar apse, early 800s, Rome. De Rossi, Musaici cristiani, pl. "Abside de Santa Maria in Dominica"

\section{Women with the Cloth of the Eucharistic Officiant}

The very oldest surviving church decoration dated with certainty that portrays someone holding the Eucharistic cloth is a wall mosaic approximately the same age as the fifth-century ivory diptych that depicts 
the four evangelists holding their gospel books with the cloth. ${ }^{109}$ The mosaic illustrates a woman holding the cloth. This woman is one of two women, each called "church," and each holding a large open book. ${ }^{110}$ Both mosaics are in Santa Sabina Basilica in Rome and dated 430 to 440. Originally, mosaics of Peter and Paul were on the wall directly above the two women. ${ }^{111}$ One of the women, titled "Church of the Circumcision," holds a large open book that appears to represent the Jewish scriptures, given the square blocks that depict the writing on its pages. The other woman, titled "Church of the Gen tiles," also holds a large open book, and it appears to be the Greek gospels, given the squiggly lines with which its writing is represented. ${ }^{112}$ Similar to the ivory diptych that depicts the four evangelists using the cloth to hold their gospel book, the woman holding the Greek gospels also holds the cloth. ${ }^{113}$ Despite the spread of centuries, the parallel between this woman and Pope Clement in his eleventh-century portrait at the Eucharist in Fig. 4.8 is profound. Both she and Clement are depicted holding the cloth doubled over in their left hand, adjacent a large open book. This iconographic parallel suggests that the meaning of the cloth remained constant over time, whether seen with a woman or with a man. For the mosaics of these two women, see Fig. 4.16.

The gospel book in art typically signified a bishop, and bishops were often depicted holding books. This association seems likely due to the fact that bishops, and bishops only, were ordained with the open gospel book held over their head, the same practice then as today. ${ }^{114}$ This ritual of "holding the divine Gospels open upon the head" as part of the episcopal ordination ritual is found in the fourth-century Apostolic Constitutions, itself compiled from the older Apostolic Tradition. ${ }^{115}$ According to the popular preacher and bishop, Severian of Gabala (ca. 380-425), the imposition of the gospel book was an integral part of a bishop's ordination ritual in order that, just as in the upper room at Pentecost, the Holy Spirit's tongues of flame would descend from the book to ordain and inspire the new bishop's preaching. ${ }^{116}$

The proposition that this open gospel book was an allusion to the episcopacy in this mosaic is furthered by another mosaic installed in Rome perhaps ten years later. In the Maria Maggiore Basilica, Peter and Paul, the archetypical bishops themselves, are seen holding out open books on either side of an empty episcopal throne. ${ }^{117}$ Peter and Paul holding out their open books toward the empty bishop's throne seem to signify that they are waiting to ordain the new bishop of Rome. ${ }^{118}$ This iconography was particularly poignant, because Pope Celestine 

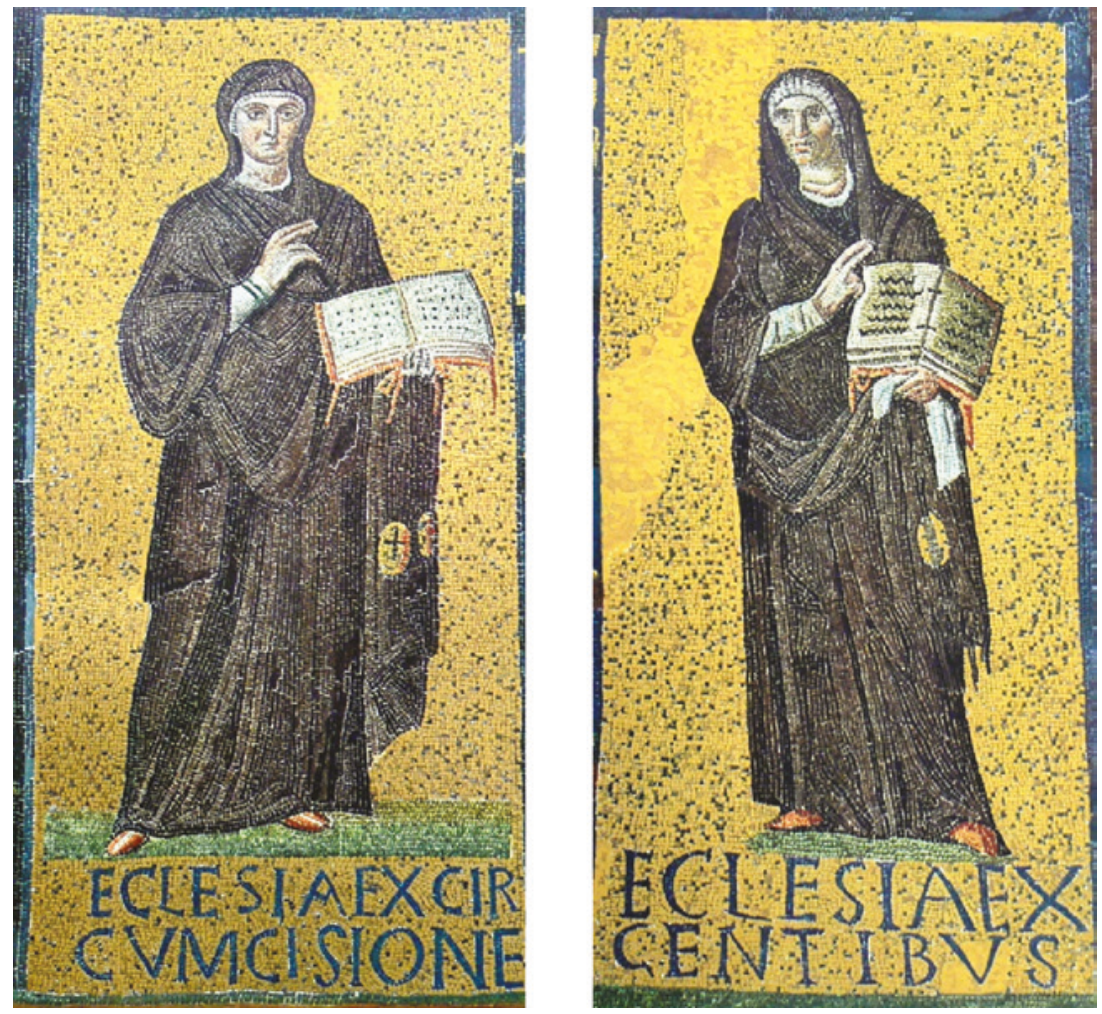

Fig. 4.16 The two "Churches." Church of the Gentiles (right) holds the cloth. 420 to 430. Santa Sabina Basilica. Wilpert, Römischen Mosaiken, pl. 47

(r. 422-432), who most likely started construction on Maria Maggiore, died before that enormous basilica was completed. ${ }^{119}$

The earlier composition of the two women holding open books in Santa Sabina likewise presents them as if authorizing the bishop of Rome-as if authorizing the bishop of Rome over all other bishops. The two women held their open books on either side of a large dedicatory inscription that began with these words: "When Celestine held the apostolic eminence shining as the foremost bishop in the whole world ..."120 This was a very early elevation of the Bishop of Rome over all others. One might conclude that the mosaic of these two women, both titled "church," one also holding the Eucharistic cloth, signified women bishops, just as the figures 
of Peter and Paul holding open books signified bishops. In addition, Mary herself was called "the Church," from at least the time of Clement of Alexandria - who said that he loved to call her "the Church."121 As we will see in the next chapter, and potentially explaining why there were two "churches" in this mosaic, a decade later in the Maria Maggiore mosaics, two Marys were present at the Adoration of the Magi. ${ }^{122}$

In any case, ten years later in the city of Rome, Peter and Paul, men in the male line of apostolic succession, were depicted holding an open book. We therefore reasonably may consider the conclusion that two women holding an open book were a symbol of high female episcopal authority. This conclusion is buttressed by two facts. First, one of the two women depicted also holds the Eucharistic cloth. Second, both of the very oldest artifacts to depict someone with the Eucharistic cloth in a liturgical procession depicted women, not men, with the cloth.

Three of Theodora's ladies were depicted with the narrow white fringed cloth in one of the two altar apse mosaics installed in the midsixth-century Basilica of San Vitale in Ravenna. Almost certainly the ivory throne of Bishop Maximianus, with its carvings of the four evangelists holding a gospel book with the cloth as well as two men using the cloth to hold a platter of bread or fish, was in the Holy of Holies below the mosaic. This mosaic depicted two women with the white fringed cloth hanging from their girdle and one woman holding it doubled over in her hand. Theodora herself, the Augusta, holds the jeweled Eucharistic chalice. ${ }^{123}$ I discuss this mosaic in more detail in Chapter 7, but for now, I quote Alexei Lidov, who says: "Let me remind those who are convinced of the lay provenance of the handkerchief that Theodora with her retinue, as well as Justinian, are presented in San Vitale in a liturgical procession in the sanctuary, both holding liturgical vessels - the Chalice and Paten"124 (see Fig. 4.17).

The second artifact that depicts women in a liturgical procession, in this case wearing the narrow folded cloth hanging from their girdles, is the sixth-century ivory pyx previously seen in Fig. 2.8a, b. This sculptor carved women processing to the Anastasis altar, with two women holding censers approaching the altar from either side. All five women in this procession were sculpted with the cloth hanging from their girdles. The cloth is most clearly represented as two strips on the center arms-raised woman (see Fig. 4.18).

Both the San Vitale mosaic and the ivory pyx substantiate that the cloth was associated not only with Mary's Eucharistic and episcopal 


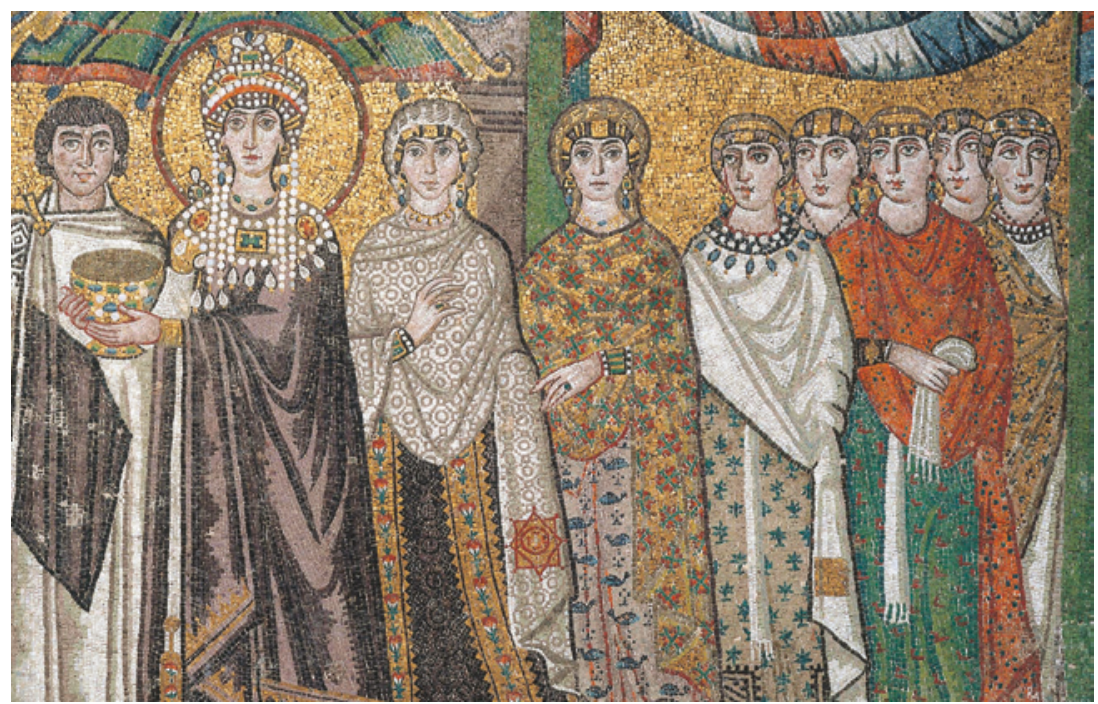

Fig. 4.17 Theodora with the chalice and three women with the cloth. Wall mosaic to the right of the altar. Ca. 550. San Vitale Basilica, Ravenna. (C) Alinari Archives-Alinari Archive, Florence

authority, but also with women's authority, the same type of authority with which the cloth was associated when used by men. The idea that this narrow white cloth meant something different when used by a woman during the liturgy than when used by a man is a circular argument predicated on the demonstrably false premise that no women during this era were clergy. ${ }^{125}$ We are not logically obliged to interpret the authority that this cloth represented differently because it is seen as part of a woman's vestments. The logical conclusion is that this cloth was always associated with power and authority in the church, and only later, much later, became restricted to men.

The faux-Paul author of the New Testament letter 1 Timothy challenged the authority of women in the assembly. Various pieces of evidence indicate that this challenge was made because some communities of Jesus followers supported women as well as men in ecclesial leadership roles. The evidence also indicates that these communities ignored 1 Timothy (if they even knew about it). These communities continued to support women as church leaders. Community support for these women leaders 


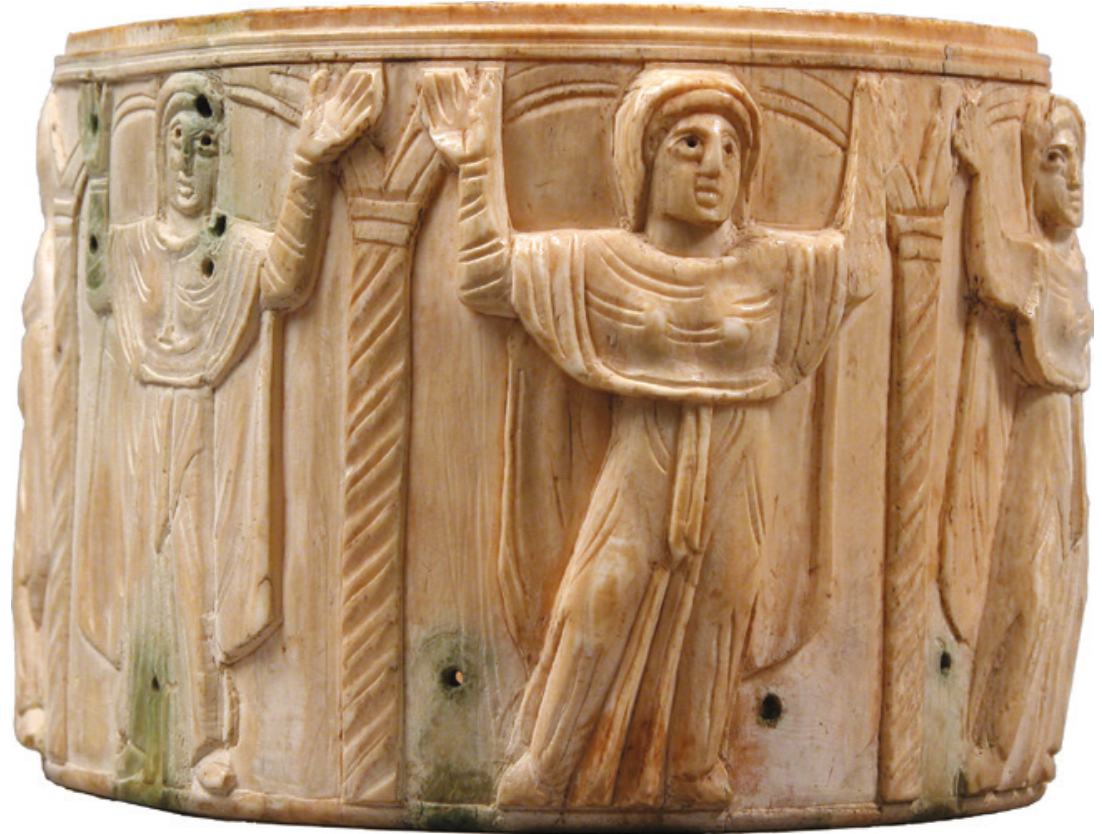

Fig. 4.18 Arms-raised women with two strips of cloth hanging from their girdles. Procession to the altar. Ivory pyx ca. 500s, Palestine. Metropolitan Museum of Art, New York City. Gift of J. Pierpont Morgan, 1917. Accession Number: 17.190.57a, b. CC0

is evidenced in the way that women, including the mother of Jesus, were depicted as church leaders, including in the episcopal role, in church art. Just as women were portrayed liturgically using censers as early as men, these episcopal vestments are seen with women as early as with men.

Around the Mediterranean, Mary was depicted wearing the episcopal pallium as well as wearing, or holding, the cloth used while officiating at the Eucharist. Mary's image in the apse of a church was placed directly above the bishop's throne and the altar table. In this setting, she was variously depicted as bishop of bishops, high priest, and Eucharistic officiant, all of which imbued her image with enormous sacral authority and power. It thus seems quite possible that during this era Mary's image functioned both as a gender ideal for women clergy and also as a guarantor of their office. 
Open Access This chapter is licensed under the terms of the Creative Commons Attribution-NonCommercial-NoDerivatives 4.0 International License (http://creativecommons.org/licenses/by-nc-nd/4.0/), which permits any noncommercial use, sharing, distribution and reproduction in any medium or format, as long as you give appropriate credit to the original author(s) and the source, provide a link to the Creative Commons licence and indicate if you modified the licensed material. You do not have permission under this licence to share adapted material derived from this chapter or parts of it.

The images or other third party material in this chapter are included in the chapter's Creative Commons licence, unless indicated otherwise in a credit line to the material. If material is not included in the chapter's Creative Commons licence and your intended use is not permitted by statutory regulation or exceeds the permitted use, you will need to obtain permission directly from the copyright holder.

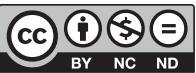

